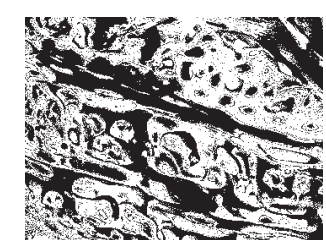

https://doi.org/10.5559/di.26.1.01

\title{
EMOTIONAL COMPETENCE AND COMBAT-RELATED PTSD SYMPTOMS IN CROATIAN HOMELAND WAR VETERANS
}

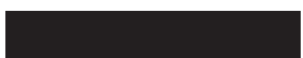

Martina KNEŽEVIĆ

Croatian Studies, Zagreb

Dino KRUPIĆ

Faculty of Humanities and Social Sciences, Osijek

Sandra ŠUĆUROVIĆ

Assembly of Associations of Croatian Guard Units Veterans, Zagreb

UDK: 159.942-057.36-058.65(497.5):616.89

Izvorni znanstveni rad

Primljeno: 29. 4. 2016.

Acknowledgements

This research was supported by a grant from the Ministry of Veterans' Affairs of the Republic of Croatia. We sincerely thank the veterans who participated in this study.
This study examined the relationship between four factors of posttraumatic stress disorder symptoms - re-experiencing, avoidance, dysphoria and hyperarousal - and particular domains of emotional competence and emotional regulation and control among 215 Croatian Homeland War veterans. Cross-sectionally, emotional competence subscales - perceiving and understanding emotions, expressing and labelling emotions, managing and regulating emotions - were associated with dysphoria symptom cluster only, while emotional regulation and control subscales influence of emotion and mood on memory and emotional reaction control - were associated with dysphoria and re-experiencing symptom clusters. The results of this study are consistent with the view that successful recovery from trauma requires adaptive emotion competence skills and that therefore difficulties in dealing with emotions (understanding, expressing or regulating) are a risk factor for the development and/or maintenance of posttraumatic stress disorder symptoms. It appears that interventions organized toward improving emotional competence and regulation may be useful as complementary or independent treatments for combat-related posttraumatic stress disorder.

Keywords: war veterans, dysphoria, re-experiencing, emotional competence, PTSD symptom clusters, Croatian Homeland War

\ Martina Knežević, Psychology Department, Croatian Studies, University of Zagreb, Borongajska cesta 83d, 10000 Zagreb, Croatia.

E-mail: mknezevic@hrstud.hr 
Emotional competence refers to the ability to recognize the meaning of emotional patterns and to solve problems that appear in emotional context (Mayer, Roberts, \& Barsade, 2008; Mayer \& Salovey, 1993). It is usually described as a set of four abilities: (1) the ability to accurately perceive, appraise and express emotions, (2) the ability to access and generate feelings when they facilitate thought, (3) the ability to understand emotions, including general knowledge about emotions, and (4) the ability to regulate emotions promoting emotional and intellectual growth (Mayer et al., 2008). Emotional competence positively correlates with pro-social behaviour (Brackett, Mayer, \& Warner, 2004), optimism and psychological well-being (Augusto-Landa, Pulido-Martos, \& Lopez-Zafra, 2011), higher self-monitoring in social situations (Rani, Priyadharshini, \& Kannadasan, 2011), social skills (Brackett, Rivers, Shiffman, Lerner, \& Salovey, 2006) and marital satisfaction (Aliakbari Dehkordi, 2012).

Low emotional competence or non-acceptance and lack of understanding of emotions may cause and prolong emotional distress, especially in people struggling with consequences of trauma (Rauch \& Foa, 2006). When people are faced with trauma that involves actual or perceived threat to life or physical integrity, their emotional reactions are characterized by horror, terror or helplessness. If these feelings stay on, interfering with daily functioning, they can cause an anxiety disorder known as posttraumatic stress disorder (PTSD) (Armour, 2015). An individual can develop PTSD after exposure to terrifying and life-threatening events including combat, motor-vehicle accidents, natural disasters, and physical or sexual assault (Gutner, Rizvi, Monson, \& Resick, 2006; Palmieri \& Fitzgerald, 2005).

PTSD is related to various emotional disturbances, including low emotional awareness and poor emotion regulation. It has been found to be related to suppression of emotions (Boden et al., 2013), emotional dysregulation (Ehring \& Quack, 2010; Kashdan, Breen, \& Julian, 2010; Price, Monson, Callahan, \& Rodriguez, 2006), and avoidance of uncomfortable internal experiences (Bensimon et al., 2013; Kashdan et al., 2010). For example, Tull, Barrett, McMillan, and Roemer (2007) found an association between PTSD symptom severity and lack of emotional acceptance, difficulties in impulse-control, ineffective emotional regulation and lack of emotional clarity in trauma exposed individuals. Monson, Price, Rodriguez, Ripley, and Warner (2004) found an association between difficulties with describing emotions and avoidance of internal emo- 
DRUŠ. ISTRAŽ. ZAGREB GOD. 26 (2017), BR. 1 STR. $1-18$

KNEŽEVIĆ, M., KRUPIĆ D., ŠUĆUROVIĆ, $S$. EMOTIONAL... tional experiences and greater PTSD symptom severity. Difficulties with emotion regulation are reflected in symptoms of PTSD that are included in DSM-IV diagnosis. These symptoms encompass heightened reactivity to cues that resemble the traumatic event, emotional numbing, loss of interest, fear and avoidance behaviour, as well as constant alertness and irritability (Ehring \& Quack, 2010). They can be classified into four clusters: (1) re-experiencing, e.g. recurrent recollections of the event through dreams or memories, (2) avoidance, e.g. of people, places or feelings that are related to the traumatic event, (3) hyperarousal, e.g. constantly feeling "on edge", and (4) dysphoria, e.g. detachment from other people or difficulties enjoying things (Armour, 2015; Bensimon et al., 2013; Olff, Sijbrandij, Opmeer, Carlier, \& Gersons, 2009; Wilkins, Lang, \& Norman, 2011).

PTSD symptoms are not mitigated by the passage of time. A high prevalence of PTSD symptoms has been found among war veterans even 30 years after the war (Boscarino, 2006; Zerach, Greene, Ginzburg, \& Solomon, 2014). War trauma is related to higher suicide (Bush et al., 2013; Wisco et al., 2014) and mortality rates (Boscarino, 2006), mental health problems (Hoge et al., 2004; Kline et al., 2010; Peterson, Luethcke, Borah, Borah, \& Young-McCaughan, 2011) and physical health problems (Kline et al., 2010) among war veterans. Recent theoretical models suggest that a central feature of PTSD is a pathological disruption of efforts that an individual undertakes to alter emotional and/or behavioural responses, which are essential for well-being (Kashdan et al., 2010). According to emotional processing theory (Foa \& Kozak, 1986; Rauch \& Foa, 2006), anxiety disorders such as PTSD are underlined by specific pathological fear structures which involve excessive responses to emotional stimuli and struggle with or even resistance to changing the unrealistic fear structure, thereby reducing pathological symptoms. Fear becomes problematic when it is so intense that it interferes with everyday functioning, because it remains active even when there are no indications of threat or danger.

Although the Homeland War ended more than 20 years ago, Croatian war veterans are still a largely understudied group. PTSD symptoms have been shown to persist even years after the end of the war in Croatia (Priebe et al., 2010). Due to a lack of systematic epidemiological research, it has been suggested that the prevalence of PTSD among Croatian war veterans varies between $25-30 \%$ (Kozarić-Kovačić, Kovačić, \& Rukavina, 2007). Recent studies highlight the importance of pre- and post-war psychosocial characteristics (family stabili- 
DRUŠ. ISTRAŽ. ZAGREB GOD. 26 (2017), BR. 1, STR. 1-18

KNEŽEVIĆ, M., KRUPIĆ D., ŠUĆUROVIĆ, S.: EMOTIONAL...

\section{METHOD}

\section{Participants}

ty, social relations, poor economic conditions, subjective dissatisfaction with various areas of life, absence of concern for the health and well-being of veterans) in the development and persistence of PTSD (Begić, Sanader, \& Žunec, 2008; Komar et al., 2010; Lončar et al., 2014; Matanov et al., 2013). Therefore, the aim of this study was to investigate the relationship between PTSD symptoms and emotional competence in a sample of Croatian war veterans. Emotional competence might be particularly problematic for veterans with PTSD symptoms as a result of conflict between strivings to manage everyday emotions and ongoing emotional disturbances characteristic of the disorder. Excessive investment in handling heightened emotional reactions would leave fewer resources available for other meaningful endeavours and limit well-being (Kashdan et al., 2010). Most of the studies that investigated the association between war-related PTSD and emotions used measures of general emotional competence and regulation difficulties (Boden et al., 2013; Ehring \& Quack, 2010; Shepherd \& Wild, 2014) as well as the total score of PTSD symptoms (Boscarino, 2006; Hoge et al., 2004; Peterson et al., 2011). We decided to measure specific domains of emotional competence, as well as the four-factor model of PTSD. In this way we wanted to extend previous research by clarifying which specific domains of emotional competence are related to re-experiencing, dysphoria, avoidance and hyperarousal PTSD symptom clusters in this population. Exploration of these relationships is clinically important and may enhance our understanding of the maintenance of PTSD symptoms. Based on previous research and taking into account a bidirectional relationship between PTSD and emotional competence, we hypothesized that veterans with higher levels of emotional competence will report less PTSD symptoms, while veterans with greater difficulties in emotional regulation will report more PTSD symptoms, even when controlling for variables that may mask this relationships, such as age, socioeconomic status or medical treatment.

215 male Croatian Homeland War veterans volunteered for this study via war veteran associations. Forty-four percent $(n=94)$ of the sample were classified as PTSD positive according to the PCL-M scale. The mean total score on the PCL-M was $45.93(S D=16.63$, range $17-83)$. Details about participants' demographics, deployment and treatment according to PTSD screening status are given in Table 1. 


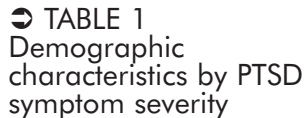

symptom severity

\begin{tabular}{llrr}
\hline & & $\begin{array}{r}\text { PTSD } \\
(n=94)\end{array}$ & $\begin{array}{r}\text { No PTSD } \\
(n=121)\end{array}$ \\
\hline Age $[M(S D)]$ & $49.51(5.77)$ & $51.22(7.63)$ \\
Months spent in Homeland War $[M(S D)]$ & $47.40(17.33)$ & $43.89(18.67)$ \\
Months spent on the frontline $[M(S D)]$ & $39.23(20.14)$ & $34.31(20.18)$ \\
Education (\%) & Elementary school & 8 & 4 \\
& High school & 84 & 82 \\
Employment status (\%) & University & 8 & 14 \\
& Employed & 5 & 17 \\
& Unemployed & 4 & 6 \\
& Military retirement & 89 & 70 \\
Civilian retirement & 2 & 7 \\
Marital status (\%) & Single & 7 & 8 \\
& Married & 75 & 84 \\
& Divorced & 15 & 6 \\
& Widower & 3 & 2 \\
Military service (\%) & Volunteered & 96 & 92 \\
& Enlisted & 3 & 7 \\
Psychiatric treatment (\%) & Other & 1 & 1 \\
& Before the war & 9 & 4 \\
& After the war & 83 & 27 \\
& Current & 66 & 11 \\
& Medication & 68 & 13 \\
\hline
\end{tabular}

\section{Procedure}

\section{Measures}

Participants were first informed about the purpose of the study through an Information letter, which also stated that their participation in the study was completely voluntary, and that they have the right to quit their participation if they did not feel comfortable continuing the process at any stage of the research. Each gave written informed consent prior to taking part in the study. Participants received an envelope containing a questionnaire about socio-demographic data, Posttraumatic stress disorder checklist - military version (PCL-M), Emotional skills and competence questionnaire (ESCQ-45), and Emotional regulation and control questionnaire (ERCQ). The testing lasted about one hour. Participants also completed the Combat exposure scale and Ways of coping questionnaire, which are described elsewhere.

A questionnaire about socio-demographic data included information on age, education, employment, marital status and children, psychiatric treatment before/after the war, current treatment, and military service entrance, duration, and termination. 
DRUŠ. ISTRAŽ. ZAGREB GOD. 26 (2017), BR. 1, STR. 1-18

KNEŽEVIĆ, M., KRUPIĆ D., ŠUĆUROVIĆ, S.: EMOTIONAL...

\section{PCL-M}

PCL-M (Weathers, Litz, Herman, Huska, \& Keane, 1993) is a 17-item screening instrument based on DSM-IV criteria for PTSD in response to "stressful military experiences". Scores are summed for each item that have response options ranging from "not at all" to "extremely". A total score ranges from 17 to 85 . The $\geq 50$ cut-point was established at the beginning of the Iraq and Afghanistan wars, and is used as a standard for military research (Wilkins et al., 2011).

\section{ESCQ-45}

ESCQ-45 (Takšić, 2002) was developed in Croatian settings using the Mayer \& Salovey (Mayer \& Salovey, 1993) emotional intelligence model. It consists of 45 items, divided into three subscales: (1) perception and understanding of emotions (PU; e.g. "I am able to tell the difference if my friend is sad or disappointed"), (2) expression and labelling of emotions (EL; e.g. "I can easily name most of my feelings"), and (3) management and regulation of emotions (MR; e.g. "I try to control unpleasant emotions, and strengthen positive ones"). Participants are asked to rate each item on a 5-point scale ranging from never to always.

\section{ERCQ-20}

ERCQ-20 (Takšić, 2003) is a 20-item scale designed to measure the effects of negative emotions and mood on participants' memory, thinking and behavioural control of emotional reactions. Participants answer each item on a 5-point scale from never to always, within 3 subscales: (1) influence of emotions and mood on memory (IEMM; e.g. "I remember well the situations in which I was angry"), (2) influence of emotions and mood on thinking (IEMT; e.g. "My mood strongly influences my thinking"), and (3) emotional reaction control (ERC; e.g. "When someone angers me, I react immediately and intensely"). The total score ranges from 20 to 100 with higher scores indicating poorer emotional regulation and control.

\section{Ethical considerations}

Data collection and privacy protection were in accordance with ethical principles, Croatian laws and international laws on the ethics of scientific research (APA). The participants were informed about the purpose of the study, assured that their participation in the study was completely voluntary and that they have the right to quit their participation at any stage if they did not feel comfortable continuing the process. The confidentiality of the data was ensured by identification numbers. 


\section{Analytic plan}

Relationships between PCL-M, ESCQ-45 and ERCQ-20 were analysed by set correlation analysis (SCA), which provides statistical control for the set of research factors (in our case age, self-rated economic status, current psychiatric treatment and medication, and the time spent on the frontline), when relating one set of variables (in our case PCL-M) to another (in our case ESCQ-45 and ERCQ-20). Furthermore, it controls covariance within both sets of variables. In this way, confounding variables and their effect are held under control, and the likelihood of Type I error is reduced, which promotes the uniqueness of the relationship between the variables (Cohen, Cohen, West, \& Aiken, 2003). Additionally, in order to further reduce Type I error due to larger number of correlations, we used the more conservative statistical significance level of $p<0.01$.

\section{RESULTS}

Descriptive statistics and intercorrelations among all variables in the study are presented in Table 2, while the results of SCA are shown in Table 3.

Using set correlation, all canonical variates in the data set were taken into account in one index, to provide the overall index of association. The overall relationship between PTSD symptoms and control variables with emotional competence was Cohen's Set Correlation $R^{2}=0.73$, which was statistically significant $F(4.81,60)=1021.48, p<0.01$. Further, a moderate to strong relationship $\left(R^{2}=0.21-0.49\right)$ between PTSD symptoms and emotional competence and emotional regulation subscales was found. Out of six control variables, none of them correlated significantly with ESCQ-45, while age and psychiatric treatment correlated positively, and months spent on the first line correlated negatively with emotional reaction control subscale. In addition, age correlated positively with influence of emotions and mood on memory and influence of emotions and mood on thinking subscales.

Dysphoria correlated negatively with all three subscales of ESCQ-45, and positively with two subscales of ERCQ-20. More specifically, war veterans with a higher level of dysphoria had lower scores on perception and understanding of emotions, expression and labelling of emotions, and management and regulation of emotions subscales, while war veterans with a higher level of dysphoria had higher scores indicating poorer regulation and control of emotions and moods on thought, as well as poorer emotional reactions control. Besides dysphoria, only re-experiencing correlated positively with one subscale of ERCQ-20 - influence of emotions and mood on thinking. 


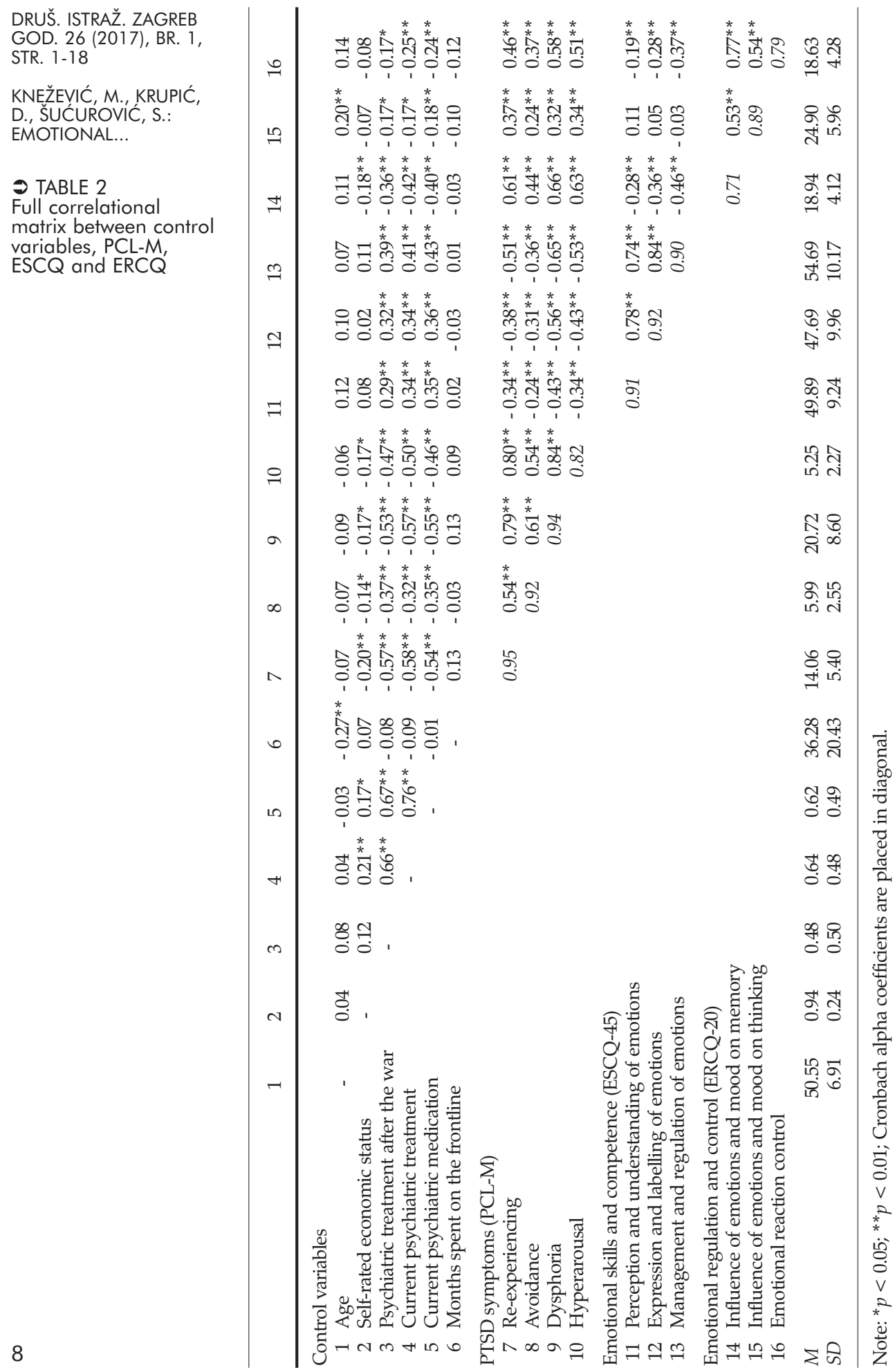




\begin{tabular}{|c|c|c|c|c|c|c|}
\hline & \multicolumn{3}{|r|}{ ESCQ } & \multicolumn{3}{|r|}{ ERCQ } \\
\hline & PU & EL & $\mathrm{MR}$ & IEMM & IEMT & ERC \\
\hline \multicolumn{7}{|l|}{ Control variables } \\
\hline Age & 0.12 & 0.07 & 0.05 & $0.15^{* *}$ & $0.21^{* *}$ & $0.15^{* *}$ \\
\hline Self-rated economic status & -0.02 & -0.07 & -0.01 & -0.04 & 0.01 & 0.03 \\
\hline Psychiatric treatment after the war & -0.02 & 0.02 & 0.03 & 0.04 & 0.01 & $0.17^{*}$ \\
\hline Current psychiatric treatment & 0.08 & 0.01 & -0.02 & -0.04 & 0.06 & 0.01 \\
\hline Current psychiatric medication & 0.16 & 0.09 & 0.13 & 0.01 & 0.02 & 0.05 \\
\hline Months on the frontline & 0.10 & 0.06 & 0.10 & -0.07 & -0.10 & $-0.17^{* *}$ \\
\hline \multicolumn{7}{|l|}{ PTSD symptoms } \\
\hline Re-experiencing & -0.04 & 0.11 & -0.04 & 0.16 & $0.32^{* *}$ & 0.10 \\
\hline Avoidance & 0.05 & 0.05 & 0.09 & 0.04 & 0.02 & 0.01 \\
\hline Dysphoria & $-0.28^{* *}$ & $-0.55^{* *}$ & $-0.51^{* *}$ & $0.38^{* *}$ & 0.06 & $0.59^{* *}$ \\
\hline Hyperarousal & 0.00 & -0.05 & -0.07 & 0.17 & 0.09 & 0.06 \\
\hline$F(10,209)$ & $5.47^{* *}$ & $9.21^{* *}$ & $13.98^{* *}$ & $20.44^{* *}$ & $5.48^{* *}$ & $14.94^{* *}$ \\
\hline$R$ & 0.46 & 0.55 & 0.63 & 0.70 & 0.46 & 0.65 \\
\hline$R^{2}$ & 0.21 & 0.31 & 0.40 & 0.49 & 0.21 & 0.42 \\
\hline
\end{tabular}

i TABLE 3

Set correlation
Note: ${ }^{*} p<0.05 ;{ }^{* *} p<0.01$; PU - perception and understanding of emotions; EL - expression and labelling of emotions; MR - management and regulation of emotions; IEMM - influence of emotions and mood on memory; IEMT - influence of emotions and mood on thinking; ERC - emotional reaction control.

\section{DISCUSSION}

This study aimed to explore whether specific domains of emotional competence are associated to the severity of re-experiencing, dysphoria, avoidance and hyperarousal PTSD symptoms in a group of Croatian war veterans. Due to highly correlated emotional competence subscales (ranging from $r=0.53$ to 0.84 ), it is not surprising that PTSD symptoms are found to correlate with all scales (see Table 2). However, when their shared variance is controlled, the relationship between emotional competence and PTSD symptoms becomes much clearer. Cross-sectionally, five out of six subscales measuring emotional competence are associated exclusively with dysphoria symptom clusters, while the influence of emotions and mood on thinking subscale is associated with re-experiencing symptom clusters.

Dysphoria PTSD symptom cluster in PCL-M includes the inability to recall aspects of trauma, loss of interest, detachment, restricted affect, sense of foreshortened future, sleep disturbance, irritability and difficulty concentrating (Pietrzak, Harpaz-Rotem, \& Southwick, 2011; Rademaker et al., 2012). All of these symptoms may disrupt the ability to assert some degree of control over emotions, including the ability to cope with 
DRUŠ. ISTRAŽ. ZAGREB GOD. 26 (2017), BR. 1, STR. 1-18

KNEŽEVIĆ, M., KRUPIĆ D., ŠUĆUROVIĆ, S.: EMOTIONAL... strong emotions, both positive and negative, without feeling overwhelmed, as well as the ability to easily transition between emotional states (Boden et al., 2013; Price et al., 2006; Shepherd \& Wild, 2014). Individuals with PTSD dedicate significant resources in order to identify, label, evaluate, manage and modify the experience and expression of their emotions (Badour \& Feldner, 2013; Tull et al., 2007) in which they are usually unsuccessful. Denial of emotions, e.g. through loss of interest or detachment, may result in the need for investment of additional resources for emotion regulation. This would reduce the individuals' resources for engagement in adaptive behaviours that may actually improve their wellbeing (Kashdan et al., 2010) and further exacerbate difficulties in dealing with trauma-related emotions. Dysphoria is often referred to as an absence of positive mood and pleasurable experiences (Zoellner, Pruitt, Farach, \& Jun, 2014). As a means of disengaging from the traumatic emotional cues, dysphoria has been described as one possibility to account for diminished emotional reactions among some individuals with PTSD (see Hassija, Jakupcak, \& Gray, 2012 for a systematic review).

Taking into account a bidirectional relationship between PTSD and emotional competence, another explanation is possible. Theories based on conditioning suggest that at the time of a traumatic event, powerful associative learning occurs during which fear responses become paired through mechanisms of classical conditioning with stimuli present during this event. The consequence of this pairing is that previously neutral cues associated with traumatic event start evoking anxious emotional reactions even when the danger is not present (Foa \& Kozak, 1986; Riggs, Rothbaum, \& Foa, 1995). Prolonged exposure to such trauma-related stimuli should reduce fear responding, a mechanism known as habituation, which is the first step of exposure therapy based on emotion processing theory (Foa \& Kozak, 1986; Gallistel \& Gibbon, 2000). Habituation should be followed by the reduction of erroneous evaluation of the probability of risk and negative valence. However, individuals with low emotional competence engage in less adaptive strategies for handling emotional reaction elicited by traumatic event cues, thus interfering with the natural extinction process needed to reduce traumatic event-related reactions (Badour \& Feldner, 2013; Tull et al., 2007). Improvement in emotional competence skills, especially emotional expression and regulation, have been shown to predict greater symptom reduction during treatments that target engagement in traumatic event cues in order to extinguish associated harmful emotional reactivity (Peterson et al., 2011; Price et al., 2006). Research suggests that low emotional com- 
DRUŠ. ISTRAŽ. ZAGREB GOD. 26 (2017), BR. 1 STR. $1-18$

KNEŽEVIĆ, M., KRUPIĆ D., ŠUĆUROVIĆ, $S$. EMOTIONAL. petence may serve as a maintaining factor for PTSD reactions (Bensimon et al., 2013; Boden et al., 2013).

Re-experiencing involves persistent and unwanted recollections of the traumatic event, intrusive memories of the event, and dissociative flashbacks, despite being removed from the traumatic situation and context. These symptoms can be frightening and highly disrupt everyday living (Ehlers, Hackmann, \& Michael, 2004). Since they are automatic and involve re-experiencing the trauma, an individual may feel as though he or she is back in danger, causing uncontrollable, distressing and highly emotional reminders of the traumatic event (Boden et al., 2013). These results are in line with the emotional processing theory of PTSD, which attribute the paradoxical increase or maintenance of re-experiencing symptoms to the inability to control the internal and external traumatic reminders (Rademaker et al., 2012). Explaining re-experiencing symptoms, Ehlers et al. (2004) suggested that if individuals do not successfully incorporate their trauma memories into context and update them with the subsequent information, re-experiencing symptoms will persist and individuals will not learn that there is no present danger, and this will further negatively influence their memory and worsen the symptoms.

The absence of a relationship between emotional competence and regulation subscales and PTSD symptoms of avoidance and hyperarousal may seem surprising. We must therefore emphasize that correlation coefficients calculated by set correlation analysis are free from confounding variance of both the predictor and criterion set of variables. High correlations among predictors may lead to increased chances of Type I error, i.e. suggest false positive effects. The main contribution of the statistical analysis used in this study is that these effects are eliminated, and the reported correlations represent a unique relationship between variables. Hence, our data suggest that PTSD dysphoria symptom cluster is related to most of the emotional competence skills. This does not diminish the relevance of other PTSD symptoms in emotional processing. Rather, our data exclude the direct, but not indirect relationship between emotional abilities and the rest of the PTSD symptoms. For example, avoidance symptoms include avoidance of people, places, thoughts and feeling closely associated with the traumatic event, so coping with emotions related to these events would be incomprehensible for them since they make additional effort to restrict the emotions they feel (Boden et al., 2013; Kashdan et al., 2010). PTSD models show a strong correlation between active or effortful avoidance and emotional difficulties (Badour \& Feldner, 2013; Brackett et al., 2004; Palmieri \& Fitzgerald, 2005; Rademaker et al., 
DRUŠ. ISTRAŽ. ZAGREB GOD. 26 (2017), BR. 1, STR. 1-18

KNEŽEVIĆ, M., KRUPIĆ D., ŠUĆUROVIĆ, S.: EMOTIONAL...
2012). Hyperarousal symptoms include difficulty with sleep and relaxing, hypervigilance, irritability and anger, poor concentration, and exaggerated startle response. It has been proposed that individuals with PTSD exhaust considerable energy in an attempt to manage their hyperarousal symptoms, which may in turn reduce their emotional resources to such an extent that they learn how to strategically avoid emotions and thus are unable to report about them (Litz et al., 1997; Tull \& Roemer, 2003). For example, one study found that Vietnam veterans with combat-related PTSD reported intentionally withholding their emotions, and as a result they exhibited more dysphoria symptoms compared to Vietnam veterans without PTSD symptoms (Roemer, Litz, Orsillo, \& Wagner, 2001).

The results of our study are consistent with the view that successful recovery from trauma requires adaptive emotion competence skills and that therefore difficulties in dealing with emotions (understanding, expressing or regulating) are a risk factor for the development and/or maintenance of PTSD symptoms. It appears that interventions organized toward improving emotional regulation may be useful as complementary or independent treatments for combat-related PTSD. Emotion regulation skills training may be a useful intervention strategy for trauma survivors, especially since it seems that these difficulties serve to maintain or exacerbate PTSD symptoms (Price et al., 2006; Tull et al., 2007). The importance of incorporating emotional competence and regulation skills training modules in PTSD treatments is highlighted in research that shows that emotion regulation difficulties reduce the effectiveness of the traditional treatments for PTSD (Brousse et al., 2011; Hayes, Vanelzakker, \& Shin, 2012; Price et al., 2006; Tull et al., 2007).

It is important to acknowledge several limitations of our study. First, our data were cross-sectional and correlational in nature, thus preventing conclusions about whether these reported emotional competence and regulation difficulties provoke or worsen PTSD symptoms or are a result of these symptoms. More research is needed to evaluate this. Another limitation is the use of self-report assessment, since respondents with low emotional competence or PTSD symptoms may have difficulties reporting about their emotions and symptoms. Clinician interviews or psychophysiological measurements of emotional reactivity would help shedding additional light on these issues. We were also limited to including an all-male sample, so our results may not generalize to combat trauma exposed women. Finally, research including individuals who experienced other types of traumatic events would further outline the complex role of emotions in the development and maintenance of PTSD. 
The aim of this study was to investigate the relationship between the four-factor model of PTSD symptoms and specific domains of emotional competence and regulation. Our findings suggest an inverse relationship between dysphoria and re-experiencing symptom severity and emotional competence and regulation abilities. It seems that war veterans with severe PTSD symptoms appear to lack the abilities to understand, express and regulate emotions. These findings highlight the complex role of emotional competence in the development and maintenance of PTSD symptoms and might be useful in identifying elements of emotional competence and regulation that may contribute to successful treatment of affective components of PTSD in the veteran population.

Aliakbari Dehkordi, M. (2012). Relationship between emotional intelligence and marital satisfaction in married women and their spouses. International Journal of Psychology, 47(S1), 181.

Armour, C. (2015). The underlying dimensionality of PTSD in the diagnostic and statistical manual of mental disorders: Where are we going? European Journal of Psychotraumatology, 6(1). https://doi.org/ 10.3402/ejpt.v6.28074

Augusto-Landa, J. M., Pulido-Martos, M., \& Lopez-Zafra, E. (2011). Does perceived emotional intelligence and optimism/pessimism predict psychological well-being? Journal of Happiness Studies, 12(3), 463-474. https://doi.org/10.1007/s10902-010-9209-7

Badour, C. L., \& Feldner, M. T. (2013). Trauma-related reactivity and regulation of emotion: Associations with posttraumatic stress symptoms. Journal of Behavior Therapy and Experimental Psychiatry, 44(1), 69-76. https://doi.org/10.1016/j.jbtep.2012.07.007

Begić, N., Sanader, M., \& Žunec, O. (2008). Ratni veterani u starom Rimu i u današnjoj Hrvatskoj (War veterans in ancient Rome and in present-day Croatia). Polemos, 10(2), 11-30.

Bensimon, M., Levine, S. Z., Zerach, G., Stein, E., Svetlicky, V., \& Solomon, Z. (2013). Elaboration on posttraumatic stress disorder diagnostic criteria: A factor analytic study of PTSD exposure to war or terror. Israel Journal of Psychiatry and Related Sciences, 50(2), 84-90.

Boden, M. T., Westermann, S., McRae, K., Kuo, J., Alvarez, J., Kulkarni, M. R., \& Bonn-Miller, M. O. (2013). Emotion regulation and posttraumatic stress disorder: A prospective investigation. Journal of Social and Clinical Psychology, 32(3), 296-314. https://doi.org/10.1521/ jscp.2013.32.3.296

Boscarino, J. A. (2006). Posttraumatic stress disorder and mortality among US army veterans 30 years after military service. Annals of Epidemiology, 16(4), 248-256. https://doi.org/10.1016/j.annepidem.2005. 03.009 
DRUŠ. ISTRAŽ. ZAGREB GOD. 26 (2017), BR. 1, STR. 1-18

KNEŽEVIĆ, M., KRUPIĆ, D., ŠUĆUROVIĆ, S.: EMOTIONAL...
Brackett, M. A., Mayer, J. D., \& Warner, R. M. (2004). Emotional intelligence and its relation to everyday behaviour. Personality and Individual Differences, 36(6), 1387-1402. https://doi.org/10.1016/S0191-8869 (03)00236-8

Brackett, M. A., Rivers, S. E., Shiffman, S., Lerner, N., \& Salovey, P. (2006). Relating emotional abilities to social functioning: A comparison of self-report and performance measures of emotional intelligence. Journal of Personality and Social Psychology, 91(4), 780-795. https://doi. org/10.1037/0022-3514.91.4.780

Brousse, G., Arnaud, B., Roger, J. D., Geneste, J., Bourguet, D., Zaplana, F., \& Jehel, L. (2011). Management of traumatic events: Influence of emotion-centered coping strategies on the occurrence of dissociation and post-traumatic stress disorder. Journal of Neuropsychiatric Disease and Treatment, 7(1), 127-133. https://doi.org/10.2147/NDT.S17130

Bush, N. E., Reger, M. A., Luxton, D. D., Skopp, N. A., Kinn, J., Smolenski, D., \& Gahm, G. A. (2013). Suicides and suicide attempts in the U.S. Military, 2008-2010. Suicide and Life Threatening Behavior, 43(3), 262-273. https://doi.org/10.1111/sltb.12012

Cohen, J., Cohen, P., West, S. G., \& Aiken, L. S. (2003). Applied multiple regression/correlation analysis in the behavioral sciences (Third Edition ed.). Mahwah, NJ: Erlbaum.

Ehlers, A., Hackmann, A., \& Michael, T. (2004). Intrusive re-experiencing in post-traumatic stress disorder: Phenomenology, theory, and therapy. Memory, 12(4), 403-415. https://doi.org/10.1080/09658210444 000025

Ehring, T., \& Quack, D. (2010). Emotion regulation difficulties in trauma survivors: The role of trauma type and PTSD symptom severity. Behaviour Therapy, 41(4), 587-598. https://doi.org/10.1016/j.beth.2010. 04.004

Foa, E. B., \& Kozak, M. J. (1986). Emotional processing of fear: Exposure to corrective information. Psychological Bulletin, 99(1), 20-35. https://doi.org/10.1037/0033-2909.99.1.20

Gallistel, C. R., \& Gibbon, J. (2000). Time, rate, and conditioning. Psychological Review, 107(2), 289-344. https://doi.org/10.1037//0033-295X. 107.2.289

Gutner, C. A., Rizvi, S. L., Monson, C. M., \& Resick, P. A. (2006). Changes in coping strategies, relationship to the perpetrator, and posttraumatic distress in female crime victims. Journal of Traumatic Stress, 19(6), 813-823. https://doi.org/10.1002/jts.20158

Hassija, C. M., Jakupcak, M., \& Gray, M. J. (2012). Numbing and dysphoria symptoms of posttraumatic stress disorder among Iraq and Afghanistan War veterans: A review of findings and implications for treatment. Behavior Modification, 36(6), 834-856. https://doi.org/10.1177/ 0145445512453735

Hayes, J. P., Vanelzakker, M. B., \& Shin, L. M. (2012). Emotion and cognition interactions in PTSD: A review of neurocognitive and neuroimaging studies. Frontiers in Integrative Neuroscience, 6, 89. https://doi. org/10.3389/fnint.2012.00089 
DRUŠ. ISTRAŽ. ZAGREB GOD. 26 (2017), BR. 1 STR. $1-18$

KNEŽEVIĆ, M., KRUPIĆ D., ŠUĆUROVIĆ, $S$. EMOTIONAL...
Hoge, C. W., Castro, C. A., Messer, S. C., McGurk, D., Cotting, D. I., \& Koffman, R. L. (2004). Combat duty in Iraq and Afghanistan, mental health problems and barriers to care. The New England Journal of Medicine, 351(1), 13-22. https://doi.org/10.1056/NEJMoa040603

Kashdan, T. B., Breen, W. E., \& Julian, T. (2010). Everyday strivings in war veterans with posttraumatic stress disorder: Suffering from a hyper-focus on avoidance and emotion regulation. Behavior Therapy, 41(3), 350-363. https://doi.org/10.1016/j.beth.2009.09.003

Kline, A., Falca-Dodson, M., Sussner, B., Ciccone, D. S., Chandler, H., Callahan, L., \& Losonczy, M. (2010). Effects of repeated deployment to Iraq and Afghanistan on the health of New Jersey Army National Guard troops: Implications for military readiness. American Journal of Public Health, 100(2), 276-283. https://doi.org/10.2105/AJPH.2009.162925

Komar, Z., Lončar, M., Vukušić, H., Dijanić Plašć, I., Folnegović Goršić, P., Groznica, I. \& Henigsberg, N. (2010). Percepcija obolijevanja od PTSP-a kod hrvatskih branitelja (Perceived prevalence of PTSD in Croatian war veterans). Medix, 16(89/90), 122-124.

Kozarić-Kovačić, D., Kovačić, Z. \& Rukavina, L. (2007). Posttraumatski stresni poremećaj (Posttraumatic stress disorder). Medix, 13(71), 102-106.

Litz, B. T., Schlenger, W. E., Weathers, F. W., Caddell, J. M., Fairbank, J. A., \& LaVange, L. M. (1997). Predictors of emotional numbing in posttraumatic stress disorder. Journal of Traumatic Stress, 10(4), 607-618. https://doi.org/10.1002/jts.2490100407

Lončar, M., Dijanić Plašć, I., Bunjevac, T., Hrabač, P., Jakšić, N., Kozina, S., Henigsberg, N., Šagud, M., \& Marčinko, D. (2014). Predicting symptom clusters of posttraumatic stress disorder (PTSD) in Croatian war veterans: The role of socio-demographics, war experiences and subjective quality of life. Psychiatria Danubina, 26(3), 231-238.

Matanov, A., Giacco, D., Bogić, M., Ajduković, D., Francisković, T., Galeazzi, G. M., Kucukalić, A., Lecić-Toševski, D., Morina, N., Popovski, M., Schützwohl, M., \& Priebe, S. (2013). Subjective quality of life in war affected populations. BMC Public Health, 13(624). https://doi.org/10.1186/1471-2458-13-624

Mayer, J. D., Roberts, R. D., \& Barsade, S. G. (2008). Human abilities: Emotional intelligence. Annual Review of Psychology, 59, 507-536. https://doi.org/10.1146/annurev.psych.59.103006.093646

Mayer, J. D., \& Salovey, P. (1993). The intelligence of emotional intelligence. Intelligence, 17(4), 433-442. https://doi.org/10.1016/0160-2896 (93)90010-3

Monson, C. M., Price, J. L., Rodriguez, B. F., Ripley, M. P., \& Warner, R. A. (2004). Emotional deficits in military-related PTSD: An investigation of content and process disturbances. Journal of Traumatic Stress, 17(3), 275-279. https://doi.org/10.1023/B:JOTS.0000029271.58494.05

Olff, M., Sijbrandij, M., Opmeer, B. C., Carlier, I. V. E., \& Gersons, B. P. R. (2009). The structure of acute posttraumatic stress symptoms: 'Reexperiencing', 'Active avoidance', 'Dysphoria', and 'Hyperarousal'. Journal of Anxiety Disorders, 23(5), 656-659. https://doi.org/10.1016/ j.janxdis.2009.02.003 
DRUŠ. ISTRAŽ. ZAGREB GOD. 26 (2017), BR. 1, STR. 1-18

KNEŽEVIĆ, M., KRUPIĆ, D., ŠUĆUROVIĆ, S.: EMOTIONAL...
Palmieri, P. A., \& Fitzgerald, L. R. (2005). Confirmatory factor analysis of posttraumatic stress symptoms in sexually harassed women. Journal of Traumatic Stress, 18(6), 657-666. https://doi.org/10.1002/jts. 20074

Peterson, A. L., Luethcke, C. A., Borah, E. V., Borah, A. M., \& Young-McCaughan, S. (2011). Assessment and treatment of combat-related PTSD in returning war veterans. Journal of Clinical Psychology in Medical Settings, 18(2), 164-175. https://doi.org/10.1007/s10880-011-9238-3

Pietrzak, R. H., Harpaz-Rotem, I., \& Southwick, S. M. (2011). Cognitive-behavioral coping strategies associated with combat-related PTSD in treatment-seeking OEF-OIF Veterans. Psychiatry Research, 189(2), 251-258. https://doi.org/10.1016/j.psychres.2011.07.019

Price, J. L., Monson, C. M., Callahan, K., \& Rodriguez, B. F. (2006). The role of emotional functioning in military-related PTSD and its treatment. Journal of Anxiety Disorders, 20(5), 661-674. https://doi.org/ 10.1016/j.janxdis.2005.04.004

Priebe, S., Bogic, M., Ajdukovic, D., Franciskovic, T., Galeazzi, G. M., Kucukalic, A., Lecic-Tosevski, D., Morina, N., Popovski, M., Wang, D., Schutzwhol, M. (2010). Mental disorders following war in the Balkans: A study in 5 countries. Archives of General Psychiatry, 67(5), 518-528. https://doi.org/10.1001/archgenpsychiatry.2010.37

Rademaker, A. R., van Minnen, A., Ebberink, F., van Zuiden, M., Hagenaars, M. A., \& Geuze, E. (2012). Symptom structure of PTSD: Support for a hierarchical model separating core PTSD symptoms from dysphoria. European Journal of Psychotraumatology, 3(1). https://doi. org/10.3402/ejpt.v3i0.17580

Rani, C. S., Priyadharshini, R. G., \& Kannadasan, T. (2011). The influence of the emotional intelligence on self monitoring. African Journal of Business Management, 5(21), 8487-8490. https://doi.org/10.5897/AJBM 11.640

Rauch, S. A. M., \& Foa, E. B. (2006). Emotional Processing Theory (EPT) and exposure therapy for PTSD. Journal of Contemporary Psychotherapy, 36, 61-65. https://doi.org/10.1007/s10879-006-9008-y

Riggs, D. S., Rothbaum, B. O., \& Foa, E. B. (1995). A prospective examination of symptoms of posttraumatic-stress-disorder in victims of nonsexual assault. Journal of Interpersonal Violence, 10(2), 201-214. https://doi.org/10.1177/0886260595010002005

Roemer, L., Litz, B. T., Orsillo, S. M., \& Wagner, A. W. (2001). A preliminary investigation of the role of strategic withholding of emotions in PTSD. Journal of Traumatic Stress, 14(1), 149-156. https://doi. org/10.1023/A:1007895817502

Shepherd, L., \& Wild, J. (2014). Emotion regulation, physiological arousal and PTSD symptoms in trauma-exposed individuals. Journal of Behavior Therapy and Experimental Psychiatry, 45(3), 360-367. https://doi. org/10.1016/j.jbtep.2014.03.002

Takšić, V. (2002). Upitnici emocionalne inteligencije (kompetentnosti) UEK (The questionnaires of emotional intelligence and competence), Vol. 1. Zadar: Odjel za psihologiju Sveučilišta u Zadru.

Takšić, V. (2003). Skala emocionalne regulacije i kontrole (ERIK): provjera faktorske strukture (Emotional regulation and control questionnaire (ERCQ): Factor structure. Psihologijske teme, 12(1), 43-54. 
DRUŠ. ISTRAŽ. ZAGREB GOD. 26 (2017), BR. 1 STR. $1-18$

KNEŽEVIĆ, M., KRUPIĆ D., ŠUĆUROVIĆ, $S$. EMOTIONAL.
Tull, M. T., Barrett, H. M., McMillan, E. S., \& Roemer, L. (2007). A preliminary investigation of the relationship between emotion regulation difficulties and posttraumatic stress symptoms. Behavior Therapy, 38(3), 303-313. https://doi.org/10.1016/j.beth.2006.10.001

Tull, M. T., \& Roemer, L. (2003). Alternative explanations of emotional numbing of posttraumatic stress disorder: An examination of hyperarousal and experiential avoidance. Journal of Psychopathology and Behavioral Assessment, 25(3), 147-154. https://doi.org/10.1023/A:1023 568822462

Weathers, F., Litz, B., Herman, D., Huska, J., \& Keane, T. (1993). The PTSD checklist (PCL): Reliability, validity, and diagnostic utility. Paper presented at the Annual Convention of the International Society for Traumatic Stress Studies, San Antonio, TX.

Wilkins, K. C., Lang, A. J., \& Norman, S. B. (2011). Synthesis of the psychometric properties of the PTSD checklist (PCL) military, civilian, and specific versions. Depression and Anxiety, 28(7), 596-606. https://doi.org/10.1002/da.20837

Wisco, B. E., Marx, B. P., Wolf, E. J., Miller, M. W., Southwick, S. M., \& Pietrzak, R. H. (2014). Posttraumatic stress disorder in the US veteran population: Results from the National Health and Resilience in Veterans Study. Journal of Clinical Psychiatry, 75(12), 1338-1346. https://doi. org/10.4088/JCP.14m09328

Zerach, G., Greene, T., Ginzburg, K., \& Solomon, Z. (2014). The relations between posttraumatic stress disorder and persistent dissociation among ex-prisoners of war: A longitudinal study. Psychological Trauma-Theory Research Practice and Policy, 6(2), 99-108. https://doi.org/10. 1037/a0031599

Zoellner, L. A., Pruitt, L. D., Farach, F. J., \& Jun, J. J. (2014). Understanding heterogeneity in PTSD: Fear, dysphoria, and distress. Depression and Anxiety, 31(2), 97-106. https://doi.org/10.1002/da.22133

\section{Emocionalna kompetencija i simptomi posttraumatskoga stresnog poremećaja kod veterana Domovinskog rata}

Martina KNEŽEVIĆ

Hrvatski studiii, Zagreb

Dino KRUPIĆ

Filozofski fakultet, Osijek

Sandra ŠUĆUROVIĆ

Zbor udruga veterana hrvatskih gardijskih postrojbi, Zagreb

U ovom istraživanju ispitivali smo povezanost četiriju fakłora posttraumatskoga stresnog poremećaja - ponovno proživljavanje traume, izbjegavanje, disforija i pojačana pobuđenost - i određenih aspekata emocionalne kompetencije i emocionalne regulacije i kontrole na uzorku od 215 branitelja Domovinskog rata. Podskale emocionalne 
DRUŠ. ISTRAŽ. ZAGREB GOD. 26 (2017), BR. 1, STR. 1-18

KNEŽEVIĆ, M., KRUPIĆ, D., ŠUĆUROVIĆ, S.: EMOTIONAL... kompetencije - percipiranje i razumijevanje emocija, izražavanje i imenovanje emocija, upravljanje i reguliranje emocijama - povezane su sa simptomima faktora disforije, koji uključuju ograničeni afekt, poteškoće u spavanju, osjećaj uskraćene budućnosti, otežano koncentriranje i iritabilnost, dok su podskale emocionalne regulacije i kontrole - utjecaj emocija i raspoloženja na pamćenje i kontrola emocionalnih reakcija - povezane sa simptomima disforije i simptomima ponovnoga proživljavanja traume, npr. aktualna i intruzivna uznemirujuća prisjećanja, aktualni uznemirujući snovi, ponašanja ili osjećaji kao da se događaji ponovno zbivaju te intenzivni psihološki distres. Rezultati istraživanja sugeriraju da su poteškoće u procesiranju i reguliranju emocija mogući rizični faktor za razvoj i/ili održavanje simptoma posttraumatskoga stresnog poremećaja.

Ključne riječi: emocionalna kompetencija, PTSP, veterani, Domovinski rat, disforija

\section{(ㄷ)(1)(8)}

Međunarodna licenca / International License:

Creative Commons Attribution-NonCommercial-NoDerivatives 4.0. 